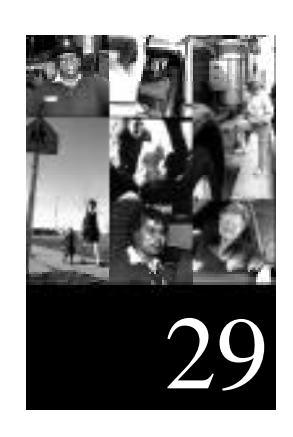

\title{
Air Bags and Children: Results of National Highway Traffic Safety Administration Special Investigation Into Actual Crashes
}

Flaura Koplin Winston Children s Hospital of Philadelphia

Richard Reed National Highway Traffic Safety Administration 


\title{
AIR BAGS AND CHILDREN: RESULTS OF NATIONAL HIGHWAY TRAFFIC SAFETY ADMINISTRATION SPECIAL INVESTIGATION INTO ACTUAL CRASHES
}

\begin{abstract}
Air bags have been and continue to be an effective, lifesaving technology. The National Highway Traffic Safety Administration (NHTSA) has estimated that air bags have saved almost 1,500 lives, with an estimated 569 lives saved in 1995 alone. However, the increasing availability of air bags in passenger vehicles and light trucks has seen a concomitant rise in the report of injuries related to air bag deployment. While the vast majority of these injuries has been minor, the exposure of children to passenger-side air bag deployments has resulted in reports of more serious injuries. The objective of this study was to examine the interaction of air bags and children in actual crash scenarios. Investigations were conducted as part of the NHTSA's Special Crash Investigation Program. This paper will present a case series of more than twenty serious or fatal injuries in children attributed to air bag deployment. Cases of children whose lives were saved by air bags, the "success stories," were not included in the series because these cases were not reported to the NHTSA. Analysis of the investigations included determination of vehicle dynamics, occupant kinematics and injury patterns in order to define injury mechanisms.
\end{abstract}

\section{BACKGROUND}

Air bags continue to save lives ${ }^{1}$. Several studies of air bag effectiveness at the NHTSA have all concluded that air bags are approximately 30 percent effective in reducing fatalities in pure frontal crashes (12:00 point of impact), and about 18 percent effective in all frontal crashes (10:00 to 2:00 point of impact). Based on these evaluations, the NHTSA has estimated that air bags have saved almost 1,500 lives, with an estimated 569 lives saved in 1995 alone. Other studies at the NHTSA have shown that air bags reduce the likelihood of non-fatal injury as well. In particular, air bags minimize the risk of life-threatening injuries to an occupant's head, neck, face, chest, and abdomen. These analyses have also shown that air bags can be associated with increased risk of arm injury ${ }^{2,3,4}$.

Air bags work optimally when deployed fully before making contact with the vehicle occupant. In the deployed state, airbags dissipate and spread the crash load and prevent occupant contact with the interior structures of the vehicle. However, if the passenger makes contact with the air bag, particularly as it is deploying, injuries may result, including abrasions, eyeglass impalement in eyes, fractures, and head injuries ${ }^{5,6,7,8,9,10}$.

In adults contact with the deploying air bag can be minimized by moving the vehicle seat rearward and using the seatbelt restraint system properly. In the optimal condition, the seatbelt limits forward movement of the occupant so that the air bag is inflated fully before making contact with the occupant. If the passenger is in close proximity to the air bag or is unrestrained, the air bag, which deploys at 140-200 mph, will make contact with the passenger. Close proximity to an air bag has been termed "out-of-position" and in these situations the air bag will add localized energy to the occupant thereby increasing the risk of injury. 


\section{AIR BAG CRASH INVESTIGATIONS AT THE NHTSA}

In order to meet its organizational mission of improving traffic safety, NHTSA has been collecting and analyzing crash and related data on various levels. The data range in sophistication from population data and the basic data contained in routine police crash reports, to the comprehensive in-depth data contained in special reports by professional crash investigation teams. At the basic level of collection, a small number of data elements are collected on the population at large and on a large number of crashes. At the most detailed level, hundreds of data elements are collected on a select number of crashes that are designated for study. Intermediate levels involve various additional data elements, not routinely collected at the basic level, in order to study some specific aspect of highway safety on a sample of crashes. The agency utilizes three distinct data collection programs to investigate and analyze air bag-related injuries: the Fatal Accident Reporting System (FARS), the National Accident Sampling System Crashworthiness Data System (NASS CDS), and the Special Crash Investigation (SCI) program.

The Fatal Accident Reporting System (FARS) is the automotive safety community's primary data source for evaluating the "global" fatality-reduction effectiveness of automotive safety features based on analysis of Police Accident Reports. FARS is a census of approximately 40,000 fatal traffic crashes per year and encompasses data from police reports and death certificates as well as State Highway Department roadway and driver licensing data bases. While FARS has been essential in revealing global trends of air bag-associated fatality and in identifying specific cases, FARS data are qualitative descriptors and lack specifications needed by automotive designers in order to improve air bag effectiveness.

The National Accident Sampling System Crashworthiness Data System (NASS CDS) is the automotive safety community's primary data source for evaluating the "global" injury-reducing effectiveness of automotive safety features. The NASS CDS has positioned crash investigation teams throughout the United States in sites representative of the geographic and demographic characteristics of the country. For a statistically representative sample of all tow-away crashes involving cars, light trucks, and vans, investigation teams collect hundreds of data elements relevant to the environment, roadway, vehicle, occupants, injuries, and safety systems involved. Currently, 24 NASS teams with a total of 60 researchers conduct approximately 5,500 investigations per year. The NASS CDS has been an invaluable data source for the automotive safety community. However, because of the size and structure of the system, it often takes one to three years to identify crash-injury trends associated with new and emerging technologies.

In order to investigate the rapidly changing innovations in automotive technology, the NHTSA created the Special Crash Investigation (SCI) Program. Since 1972, the SCI Program has conducted clinical in-depth crash investigations involving air bag-equipped vehicles. The SCI Program has provided NHTSA with the most in-depth and detailed level of crash investigation data collected by the Agency. In contrast to the NASS CDS, which reviews, collects, records, and samples hundreds of police accident reports in a particular jurisdiction, the SCI program manager selects a much smaller number of cases for investigation, 80 to 85 per year. The SCI cases are intended to be an anecdotal data set useful for examining special crash circumstances or outcomes from an engineering perspective. The benefit of this program lies in its ability to locate unique real-world crashes anywhere in the country and perform in-depth clinical investigations in a timely manner that can be utilized by the NHTSA and the automotive safety community to improve the performance of their state-of-the-art safety systems. This report describes the results to date of Special Crash Investigations of air bag injuries in children. 


\section{METHODS}

The program manager for the SCI Program receives information from an extensive and diverse network of sources. These sources include personnel from other NHTSA offices, other Federal agencies, physicians, automotive manufacturers, law enforcement agencies, consumer and legal contacts, media reports or referrals, insurance industry representatives, trauma centers, and medical examiners as well as from the general public through the automobile safety hotline.

For the current study, cases were chosen for Special Crash Investigation from crashes with passenger-side air bag deployment demonstrating unexpected severe injuries suffered by a child in a low impact collision. Once a case was identified, special crash investigation teams at Dynamic Science, Inc., Calspan, Inc., or Indiana University were dispatched to the scene to determine the pre-crash, atcrash, and post-crash vehicle dynamics and occupant kinematics. After locating the vehicles involved in the crash, the investigators photographed and measured the crash damage, identified interior locations that were struck by the occupants, obtained other scene data and photographs from the crash site, and studied evidence such as skid marks, gouges, fluid spills, and broken glass. The investigators supplemented their on-site investigations by interviewing crash victims and other involved parties, by reviewing medical records and interviewing medical personnel to determine the nature and severity of the injuries. Clinical data regarding child anthropomorphic measurements and injury patterns were provided by clinicians caring for the child and abstracted from the child's medical record.

Once all of the data were assembled, the crash was reconstructed through the use of the NHTSA's CRASH3PC and Engineering Dynamics Corporation's EDCRASH. Each investigation provided extensive information about pertinent pre-crash-, crash-, and post-crash events involving the occupants, vehicles, and rescue and environmental factors that may have contributed to the event's occurrence or resulting severity. Included in each report was an analysis and determination of the occupant kinematics and vehicle dynamics as they occurred throughout the crash. Detailed performance evaluations of the air bag and any other safety features were provided.

For a subset of the investigations, vehicles were not available for inspection (repaired, impounded, or unable to locate) or the lag time between crash date and notification was too long. For these situations, investigations were performed remote from the crash scene and were based on a review of police accident reports, medical records, and interview data rather than on detailed inspection of the scenes and vehicles.

These on-site and remote investigations formed a case series of children with air bag-induced injuries and were not a representative sample of all crashes. As such, analyses were limited to counts and descriptive summaries.

\section{RESULTS}

Tables 1 through 4 contain twenty-nine investigations of air bag-associated, critical or fatal injuries in children that were performed by the SCI Program for crashes that occurred between April 1993 and August 1996 (cases in bold indicate fatal injuries). Twenty-two of the twenty-nine crashes had occurred in the last 18 months (March 1995 through August 1996). Twenty-three of the twenty-nine investigations were performed on-site and the remainder were performed remotely. Most of the 
on-site investigations were conducted within 48 to 72 hours of the crash; some, however, due to delays in notification, were initiated up to three months after the crash.

The injured children ranged in age from one week to nine years. Seven of the eleven infants and seventeen of the eighteen children older than one year suffered fatal injuries. None of these children were between the ages of nine months and three years.

Fatalities or severe injuries in air bag-equipped vehicles quite often involve unsurvivable levels of intrusion, crashes for which the air bag would not be expected to provide a life-saving benefit (i.e., rollovers, side impacts), and multiple impact crashes, where initial deployment is of limited value in subsequent collisions. However, twenty-three of the twenty-nine cases in this series involved crash severities (DV's) of 25 kilometers per hour (15 mph) or less with ten of these at less than $16 \mathrm{kph}$ (10 $\mathrm{mph}$ ). The crash severities for the remaining six cases were estimated as follows: four were less than $30 \mathrm{kph}$, one was estimated at 32 kilometers per hour, and one at 34 kilometers per hour. In almost all cases, the drivers, many of whom were unrestrained, suffered no or minor injuries. In only one case of an infant fatality, Case CA9516, did the driver sustain a moderate injury classified as a 2 on the Abbreviated Injury Scale $90^{11}$.

Table 1

Vehicle Characteristics Associated With Air Bag-Induced Injuries in Children Older Than One Year (Bold print indicates fatal injuries)

\begin{tabular}{|c|c|c|c|c|c|c|}
\hline $\begin{array}{c}\text { Case } \\
\text { Number }\end{array}$ & $\begin{array}{l}\text { Crash } \\
\text { Date } \\
\end{array}$ & $\begin{array}{l}\text { Irvestigation } \\
\text { Date }\end{array}$ & State & Vehicle & $\begin{array}{l}\text { Crash Severity } \\
\text { (Av in kah) }\end{array}$ & $\begin{array}{c}\text { Air Bag } \\
\text { Mbdule Mburt }\end{array}$ \\
\hline CAYSJT & $4 / 93$ & $4 / 93$ & $\mathrm{OH}$ & Iyg3 Voho 85U & 11 & mid \\
\hline $\begin{array}{l}\text { CA9515 } \\
\text { Remote }\end{array}$ & $3 / 94$ & 8995 & TX & 1993 Lexws LS400 & $=20$ & mid \\
\hline $\begin{array}{l}\text { CA9443 } \\
\text { Remnte }\end{array}$ & 7194 & $12 / 94$ & VA & 1994Ford Mustang & $<20$ & mid \\
\hline DS9420 & $9 / 94$ & $12 / 94$ & UT & $\begin{array}{l}\text { 1994 Dodge Grand } \\
\text { Caravan Minivan }\end{array}$ & 13 & top \\
\hline $\begin{array}{l}\text { IN9610 } \\
\text { Remote }\end{array}$ & $12 / 94$ & $4 / 96$ & VA & 1994 Ford Aspire & $=30$ & top \\
\hline IN9508 & $3 / 95$ & $5 / 95$ & TX & $\begin{array}{l}1995 \text { Plymouth Voyager } \\
\text { Miniran }\end{array}$ & 26 & top \\
\hline $\begin{array}{l}\text { CA9523 } \\
\text { Remote }\end{array}$ & $4 / 95$ & $12 / 95$ & VT & 1993 Dodge Intrepid & 20 & top \\
\hline $\begin{array}{l}\text { IN9520 } \\
\text { Remote }\end{array}$ & $5 / 95$ & $12 / 95$ & MI & 1995 Ford Contour & 20 & top/ledge \\
\hline $\begin{array}{l}\text { ID9501 } \\
\text { Remote }\end{array}$ & $12 / 94$ & $12 / 95$ & MS & 1995 Toyota Avalon & $<15$ & mid \\
\hline CA9520 & $10 / 95$ & $10 / 95$ & UT & $\begin{array}{c}1994 \text { Chevrolet Camaro } \\
\text { Converthle }\end{array}$ & 16 & top/mid \\
\hline CA9521 & $10 / 95$ & $10 / 95$ & MD & $\begin{array}{c}1995 \text { Dodge Caravan } \\
\text { Mmiran }\end{array}$ & 20 & top \\
\hline IN9518 & 10195 & 10,95 & PA & 1995 Jaguar Corwertible & $=15$ & mid \\
\hline CA9601 & 1996 & 1996 & MI & $\begin{array}{c}1995 \text { Dodge Caravan } \\
\text { Minivan }\end{array}$ & 32 & top \\
\hline DS9605 & 4196 & $4 / 96$ & MD & 1994 Geo Metro & 17 & topimid \\
\hline IN9612 & $5 / 96$ & $5 / 96$ & $\mathrm{NC}$ & 1994 Chrysler Minivan & $\leq 20$ & top \\
\hline CA9607 & $5 / 96$ & 506 & NY & 1995 Ford Contour & 17 & top \\
\hline IN9618 & $6 / 96$ & 7996 & KS & $\begin{array}{c}1995 \text { Chewrolet Lumina } \\
\text { Sedan }\end{array}$ & $\therefore 25$ & top \\
\hline IN9619 & $8 / 96$ & $8 / 96$ & MO & $\begin{array}{c}1995 \text { Dodge Caravan } \\
\text { Miniran }\end{array}$ & $<30$ & top \\
\hline
\end{tabular}


All but three of the cases could be grouped in one of two groups: children greater than one year old and those less than one. Fifteen of the seventeen older children who were fatally injured were unrestrained right front seat occupants and the other only wore the lap portion of a lap-shoulder seat belt. The remaining older child in the series (IN9518) was a three year old who was seated in a beltpositioning booster and restrained, to some degree, by portions of the vehicle belting. This three year old was both the only older child in the series who was belted and the only older child who survived,

Table 2

Anthropomorphic and Injury Characteristics in Children Older Than One Year (Bold print indicates fatal injuries)

\begin{tabular}{|c|c|c|c|c|c|c|}
\hline $\begin{array}{c}\text { Case } \\
\text { Number }\end{array}$ & Age & $\begin{array}{l}\text { Height } \\
\text { (cm) }\end{array}$ & $\begin{array}{l}\text { Weight } \\
(\mathrm{kg})\end{array}$ & $\begin{array}{l}\text { Restraint } \\
\text { Usage }\end{array}$ & $\begin{array}{l}\text { Site of Most Severe } \\
\text { Child Irquries }\end{array}$ & $\begin{array}{l}\text { Site of Most Severe } \\
\text { Driver Injuries }\end{array}$ \\
\hline CA9307 & 6 & 111.8 & 23.2 & Nome & Brail & Minw \\
\hline $\begin{array}{l}\text { CA9515 } \\
\text { Remote }\end{array}$ & 7 & 134.6 & 35.5 & None & $\begin{array}{c}\text { Atlanto-occipital ligament } \\
\text { C-spine }\end{array}$ & None \\
\hline $\begin{array}{l}\text { CA9443 } \\
\text { Remote }\end{array}$ & 4 & 1118 & 245 & None & $\begin{array}{l}\text { Brain } \\
\text { C-spine }\end{array}$ & None \\
\hline DSy & 4 & 104.1 & 15.9 & None & Shull & Minor \\
\hline $\begin{array}{l}\text { IN9610 } \\
\text { Remote }\end{array}$ & 4 & 117 & 23 & None & $\begin{array}{c}\text { Brain, } \\
\text { Atlanto-occipital lipament }\end{array}$ & Humerus \\
\hline IN9508 & 9 & 139.7 & 29.5 & Only bap portion & $\begin{array}{c}\text { Brain } \\
\text { C-spine } \\
\end{array}$ & Minor \\
\hline $\begin{array}{l}\text { CA9523 } \\
\text { Remote }\end{array}$ & 5 & 116.8 & 20.5 & None & $\begin{array}{c}\text { Brain } \\
\text { C-spine }\end{array}$ & None \\
\hline $\begin{array}{l}\text { IN9520 } \\
\text { Remote }\end{array}$ & 5 & 106.7 & 20.5 & None & $\begin{array}{c}\text { C-spine, Neck } \\
\text { Atlanto-occipial ligament } \\
\text { Brain }\end{array}$ & Minor \\
\hline $\begin{array}{l}\text { ID9501 } \\
\text { Remote }\end{array}$ & 6 & $?$ & $?$ & None & Brain & Minor \\
\hline CA9520 & 5 & 104.1 & 25.0 & None & C-spine & Minor \\
\hline CA9521 & 7 & 1295 & 25.0 & Onhy lap portion & Brain & None \\
\hline IN9518 & 3 & 104.1 & 168 & $\begin{array}{l}\text { Belt Positioning } \\
\text { Booster }\end{array}$ & Brain & Hone \\
\hline CA960I & 9 & 137.2 & 41.0 & None & Atlanto-occipial lipament & Minor \\
\hline DS9605 & 3 & 96.5 & 13.2 & None & C-spine & $?$ \\
\hline IN9612 & 4 & 109 & 20 & None & $\begin{array}{c}\text { Brain, } \\
\text { Athanto-occipibal ligament }\end{array}$ & $?$ \\
\hline CA9607 & 7 & 123 & 227 & None & Neck, C-Spine & None \\
\hline IN9618 & 5 & $?$ & 19 & None & $\begin{array}{c}\text { Brain, } \\
\text { Atlanto-occipinal binment }\end{array}$ & Minor \\
\hline IN9619 & 4 & 122 & 23 & None & Brain & Minor \\
\hline
\end{tabular}

Table 3

Vehicle Characteristics Associated With Air Bag-Induced Injuries in Children Less Than One Year Old

(Bold print indicates fatal injuries)

\begin{tabular}{|c|c|c|c|c|c|c|}
\hline $\begin{array}{c}\text { Case } \\
\text { Number }\end{array}$ & Crash Date & $\begin{array}{l}\text { Irvestigation } \\
\text { Date }\end{array}$ & State & Vericle & $\begin{array}{c}\text { Crash Severity } \\
\left(\Delta_{\mathrm{V}} \text { in kph) }\right.\end{array}$ & $\begin{array}{c}\text { Air Bag } \\
\text { Mbdule Mount }\end{array}$ \\
\hline DS9423 & $11 / 94$ & $12 / 94$ & $\mathrm{CA}$ & 1994 Toyota Corolla & $\leq 20$ & mid \\
\hline CA9516 & 7995 & 7995 & PA & 1995 Ford Escort & 33 & mid \\
\hline DS9519 & $9 / 95$ & $12 / 95$ & $\mathrm{CA}$ & 1994 Toyota Camry & $\leq 15$ & mid \\
\hline CA9522 & $10 / 95$ & 11995 & LA & 1995 Saturn & 20 & mid \\
\hline DS9522 & 10195 & 11195 & $\mathrm{CA}$ & 1995 Ford Escort & 45 & mid \\
\hline DS9525 & 11,95 & $12 / 95$ & $\mathrm{CO}$ & 1994 Ford Aspire & $<15$ & mid \\
\hline INT9521 & 11195 & 12195 & WI & 1996 Dodge Caravan Minivan & $\leq 00$ & mid \\
\hline CA9602 & $2 / 96$ & $2 / 96$ & NJ & 1995 Isuzu Trooper & 24 & mid \\
\hline CA9608 & $4 / 96$ & 596 & FL & 1995 Hyundai Accent & $<5$ & mid \\
\hline LT96018 & $5 / 96$ & $5 / 96$ & FL & 1994 Toyota Camry & $\leq 15$ & mid \\
\hline IN9617 & $6 / 96$ & 7796 & IL & 1995 Ford Escort & $\leq 15$ & mid \\
\hline
\end{tabular}


although his injuries were severe. Crash testing was conducted by the NHTSA using an exemplar vehicle and child test dummy in order to better understand the child occupant kinematics, and NHTSA and Indiana University's Special Crash Investigation Team both concluded that the belt in this case was not properly positioned at the time of the crash. A parallel investigation conducted by the $\mathrm{Na}-$ tional Transportation Safety Board (NTSB) concluded that the child was properly belted at the time of the crash.

The older children ranged in age from three to nine years (mean 5.4 years, median 5.0 years); height range 97 to $140 \mathrm{~cm}$ (mean $116.7 \mathrm{~cm}$, median $114.3 \mathrm{~cm}$ ); and weight range from 13.2 to $41 \mathrm{~kg}$ (mean $23.4 \mathrm{~kg}$, median $23 \mathrm{~kg}$ ). The occupant kinematics sequence typical of the older unrestrained children was as follows. Avoidance braking prior to a frontal crash brought the child in close proximity to the air bag module flap. Due to the child's forward position, he/she restricted the normal air bag deployment path allowing for pressure to mount within the air bag module. Upon forceful opening of the air bag module cover flap, the child was accelerated vertically, often hitting his/her head on the windshield, followed by a rearward acceleration that resulted in hyperextension of the neck. The children died of injuries to the cervical spine and head. One of initial cases, CA9307, had a variant injury mechanism in which the child suffered no hyperextension injury of the neck but was rather lifted vertically into the roof/dome light area which resulted in fatal brain injuries without cervical spine injury.

The other group contained the eleven infants all of whom were seated in rear-facing safety seats. The infants ranged in age from one week to nine months (mean 3.5 months, median 3.0 months); height range 51 to $69 \mathrm{~cm}$ (mean $59.7 \mathrm{~cm}$, median $61.0 \mathrm{~cm}$ ); and weight range from 4.5 to $10 \mathrm{~kg}$ (mean $7.4 \mathrm{~kg}$, median $8.0 \mathrm{~kg}$ ). Typical of this series, the baby was seated in a rear-facing child safety seat placed in the right front passenger position. The close proximity of the rear of the safety seat to the air bag module resulted in rearward displacement of the safety seat upon contact with either the air bag module flap or the air bag module cover. More than half involved contact with the cover flap and

Table 4

Anthropometric and Injury Characteristics in Children Less Than One Year (Bold print indicates fatal injuries)

\begin{tabular}{|c|c|c|c|c|c|c|}
\hline $\begin{array}{c}\text { Case } \\
\text { Number }\end{array}$ & Aze & $\begin{array}{l}\text { Heizht } \\
\text { (cm) }\end{array}$ & $\begin{array}{l}\text { Weizht } \\
(\mathrm{kg})\end{array}$ & $\begin{array}{l}\text { Restrairt } \\
\text { Usage }\end{array}$ & $\begin{array}{l}\text { Site of Most Severe } \\
\text { Child Iruuries }\end{array}$ & $\begin{array}{l}\text { Site of Most Severe } \\
\text { Driver Iruures }\end{array}$ \\
\hline DS9423 & 3 months & 50.8 & 59 & $\begin{array}{l}\text { Rear-facing } \\
\text { Safaty Seat }\end{array}$ & Skull & Wrist \\
\hline CA9516 & 3 weeks & 61.0 & 5.0 & $\begin{array}{l}\text { Rear-facing } \\
\text { Safety Seat }\end{array}$ & $\begin{array}{l}\text { Skull } \\
\text { Brain }\end{array}$ & Pelvis \\
\hline DS9519 & 5 months & 68.6 & 9.1 & $\begin{array}{l}\text { Rear-facing } \\
\text { Safty Seat }\end{array}$ & $\begin{array}{l}\text { Shull } \\
\text { Brain }\end{array}$ & Minor \\
\hline CA9522 & 4 months & 610 & 7.7 & $\begin{array}{l}\text { Rear-facing } \\
\text { Safety Seat }\end{array}$ & $\begin{array}{l}\text { Shrull } \\
\text { Brain }\end{array}$ & None \\
\hline D39522 & $\sigma_{\text {rtuurtlto }}$ & 61.0 & 10.0 & $\begin{array}{l}\text { Ruar-Facirs } \\
\text { Safety Seat }\end{array}$ & $3 \mathrm{kull}$ & Mirur \\
\hline DS9525 & 3 months & $?$ & $?$ & $\begin{array}{l}\text { Rear-facing } \\
\text { Safaty Seat }\end{array}$ & $\begin{array}{l}\text { Skull } \\
\text { Brain }\end{array}$ & Hone \\
\hline IN9521 & 7 weeks & 55.9 & 45 & $\begin{array}{l}\text { Rear-facing } \\
\text { Safety Seat }\end{array}$ & Skull & Minor \\
\hline $\mathrm{CA} 9602$ & 4 months & 61 & 9.1 & Rear-facing & Brain & None \\
\hline CA9608 & 3 months & 58.4 & 8.2 & $\begin{array}{l}\text { Rear-facing } \\
\text { Safety Seat }\end{array}$ & $\begin{array}{l}\text { Shall } \\
\text { Brain }\end{array}$ & Minor \\
\hline LT96018 & 9 months & 58.4 & 8.6 & $\begin{array}{l}\text { Rear-facing } \\
\text { Safety Seat }\end{array}$ & $\begin{array}{l}\text { Shull } \\
\text { Brain }\end{array}$ & Minor \\
\hline IN9617 & I week & $?$ & $?$ & $\begin{array}{l}\text { Unattached Rear- } \\
\text { facing Safecy Seat }\end{array}$ & $\begin{array}{l}\text { Shall } \\
\text { Brain }\end{array}$ & None \\
\hline
\end{tabular}


demonstrated cracks at the site of contact with the air bag module flap cover, which were of a midmount design. A majority of the safety seats were not installed with a locking clip. The injury mechanism was thought to involve crush and resulted in skull fractures and brain injuries. The infant in case CA9516, the most severe crash severity in the series, suffered fatal brain parenchymal fracture in addition to skull fracture.

\section{DISCUSSION}

This report presents a series of twenty-nine cases of serious or fatal injuries to children attributed to air bag deployment. The crashes were investigated as part of the NHTSA Special Crash Investigation Program. A bimodal age distribution of injury mechanism was noted. Mechanism of injury to the infants in the series resulted from rearward acceleration of rear-facing infant seats that came in contact with air bag module cover flaps and the air bags. All of the vehicles in this series were equipped with air bag module flaps located in the midmount position. The infant injuries resulted from crush and included skull fracture and brain injuries. The vast majority of the older children in the series who were unbelted were placed in close proximity to the primarily top-mounted air bag modules when the driver braked pre-impact. When the air bag deployed, the children were accelerated vertically and rearward and suffered brain injuries and hyperextension injuries of the cervical spine. In all cases, the change in velocity was at most moderate but the vast majority were less than 20 kilometers per hour; the vast majority of the drivers suffered no or minor injuries but at most moderate injuries.

The severity of these air bag-associated injuries in the children in this series are in contrast to the mostly minor injuries reported in adults. Almost all of the experience in evaluating the "global effectiveness" of air bags has been based on driver-side air bags, the majority of the current air bag fleet. The passenger-side air bag fleet has been, and continues to be, too small to conduct meaningful evaluations of their lifesaving benefits. As the dual air bag fleet continues to grow, such studies will become possible. Currently, only anecdotal information, located and developed by the NHTSA's Special Crash Investigation program, is available on passenger-side air bags ${ }^{4}$.

The number of air bag vehicle crashes investigated by NASS CDS has grown dramatically, from less than 10 cases in 1988, to nearly 800 cases in 1994. In 1996, approximately 2,200 of these crashes will involve an air bag deployment. As a result of consumer demand and the congressional mandate requiring passenger-side air bags in all new passenger cars by model year 1998, and all light trucks and vans by model year 1999, a similar trend in case selection is expected for the passenger side air bag.

Cases from the 1988 through 1994 NASS CDS data files involving children seated in the right front seating position in crashes with passenger side air bag deployments are presented in Table 5 . The results of these six cases are quite different from those identified by the SCI program. It is important to note that this nationally representative statistical sample contains no AIS3 or greater injuries. This is particularly remarkable since "the current NASS CDS sampling design selects crashes which are more severe than the general crash population." 12

This discrepancy of representation of serious injuries to children in the NASS CDS data base as compared to the SCI Program can be explained in two ways. This difference may reflect the inability of the NASS CDS program to investigate crashes involving new and emerging technologies outside of the designated sampling regions, or it may reflect the main limitation of the SCI Program and, therefore, of this study, a reporting bias toward severe or fatal injuries. These tragic cases tend to gain 


\section{Women s Travel Issues}

Proceedings from the Second National Conference

rapid public awareness and are readily reported to the SCI Program while the success stories of lives saved by air bags go virtually unnoticed. Since the public expects the air bag to provide life-saving benefits, successes may not be reported because the air bag is performing as expected.

Table 5

Children and Passenger Side Air Bag Deployments 1988-1994 NASS CDS

(Only publicly available data are included in table; No fatal injuries in database.)

\begin{tabular}{|c|c|c|c|c|c|c|c|}
\hline $\begin{array}{l}\text { Aze } \\
(y r)\end{array}$ & $\begin{array}{l}\text { Heizht } \\
\text { (cm) }\end{array}$ & $\begin{array}{l}\text { Weight } \\
\text { (kg) }\end{array}$ & Vehicle & $\begin{array}{c}\text { Crash Severity } \\
\left(\Delta_{\mathrm{V}} \text { in kph) }\right.\end{array}$ & Restraint & $\begin{array}{c}\text { Maximnim } \\
\text { Abbreviated Injury } \\
\text { Scale Score } \\
\text { for Child }\end{array}$ & $\begin{array}{c}\text { Maximum } \\
\text { Abbreviated } \\
\text { Injury Scale Score } \\
\text { for Driver }\end{array}$ \\
\hline 0 & 64 & 7 & $\begin{array}{l}1993 \text { Mercury } \\
\text { Sable }\end{array}$ & 26 & $\begin{array}{l}\text { Rear-facing } \\
\text { SafetySeat }\end{array}$ & 0 & 1 \\
\hline 3 & $?$ & $?$ & 1993 B ommeville & 16 & $\begin{array}{c}\text { Fonward- } \\
\text { facing S afety } \\
\text { Seat }\end{array}$ & 1 & 0 \\
\hline 4 & 91 & 13 & 1994 VW Golf & $\leq 30$ & 3 point & 0 & 2 \\
\hline 10 & 155 & 35 & $\begin{array}{l}1994 \text { Clnysler } \\
\text { Minivan }\end{array}$ & $<30$ & 3 point & 1 & 1 \\
\hline 11 & 152 & 54 & 1992 Ford Taurus & 20 & 3 point & 1 & 1 \\
\hline 12 & 152 & 41 & $\begin{array}{l}1994 \text { Toyota } \\
\text { Corolla }\end{array}$ & 30 & 3 point & 1 & 1 \\
\hline
\end{tabular}

\section{LUIVLLUSIUINS}

In this study, two possible air bag-associated injury-producing mechanisms have been identified that require further investigation:

1. Infants in low severity frontal collisions who were seated in rear-facing child safety seats installed in the right front passenger position in close proximity to a midmount air bag.

2. Older, unbelted or improperly belted children in low severity frontal collisions who, after preimpact braking, were placed in close proximity to an air bag.

This case series may represent a few isolated tragic cases or the beginning of a new trend of air baginduced injuries in children. Over 12 million vehicles in the current fleet are equipped with passenger side air bags, but it is not known how many of these air bags have deployed with a child sitting in the right front seat. Without a true measure of the exposure of children to air bags and the true incidence of air bag injuries to children, the effectiveness of passenger side air bags in injury reduction or the injury-producing potential of air bags cannot be assessed. This information is vital to policy makers and designers.

The introduction of air bag vehicles into the driving fleet has resulted in thousands of lives saved, tens of thousands of injuries mitigated, and a reduction in the societal costs incurred as a result of motor vehicle crashes. The pivotal research and developmental roles played by NHTSA's crash investigation programs during the 1970s and 1980s, continue today with the investigation of an ever-increasing number of NASS CDS and SCI special interest air bag crashes. These air bag investigations will continue to provide the automotive safety community with valuable information. The ultimate goal of these air bag investigations and other agency programs is to improve the performance of these safety technologies and further reduce the physical and economic toll of automobile crashes. The challenge now exists to maximize the effectiveness of air bags for children and adults. 


\section{ACKNOWLEDGMENTS}

Special thanks to the Calspan Corporation, Dynamic Science, Inc., Indiana University principal investigators and investigative teams who provided the bulk of the data presented, and Carolyn de la Cruz for preparation of the manuscript. Additional acknowledgment to The Lehman Trauma Center and Information Dynamics who provided data on two additional cases.

1996 40th Stapp Car Crash Conference, Albuquerque, New Mexico, November 4-6, 1996

\section{REFERENCES}

1. J. Werner and W. Sorenson, "SAE Technical Paper 940802: Survey of Airbag Involved Accidents: An Analysis of Collision Characteristics, System Effectiveness and Injuries", 1994 SAE International Congress, February 1995.

2.Kahane, C. 1994. "Fatality Reduction by Automatic Occupant Protection in the United States," 1994 ESV, 94-55-0-08.

3. National Center for Statistics and Analysis, "Second Report to Congress: Effectiveness of Occupant Protection Systems and Their Use," Feb 1996.

4. R. Martinez, 1996. Statement Before the Senate Committee on Commerce, Science and Transportation, Regarding the Effectiveness of Air Bags, March 7, 1996.

5. R. Reed, 1994. “Air Bag Crash Investigations”, Road Traffic Safety Institute's 1994 Crash Reconstruction Conference, December 1994.

6. D.J. Dalmotas, A. German, B.E. Hendricks, R.M. Hurley, 1995. “Airbag Deployments: The Canadian Experience", The Journal of Trauma, Volume 38, Number 4.

7. D.F. Huelke, "SAE Technical Paper 950866: An Overview of Air Bag Deployments and Related Injuries. Case Studies and a Review of the Literature", 1995 SAE International Congress, March, 1995.

8. J.A. Gault, M.C. Vichnin, E.A. Jaeger, J.B. Jeffers, 1995. “Ocular Injuries Associated with Eyeglass Wear and Airbag Inflation”, The Journal of Trauma, Volume 38, Number 4.

9. D.F. Huelke, J.L. Moore, T. Compton, J. Samuels, R. Levine, 1995. "Upper Extremity Injuries Related to Airbag Deployments", The Journal of Trauma, Volume 38, Number 4.

10. D.K. Brown, E.J. Roe, T. Henry, 1995. "A Fatality Associated with the Deployment of an Automobile Airbag", The Journal of Trauma, Volume 39, Number 6.

11. Association for the Advancement of Automotive Medicine, 1990. Abbreviated Injury Scale 1990 Revision.

12. National Center for Statistics and Analysis, "Injuries Associated with Air Bag Deployments", November, 1992. 